\title{
Chemical composition and sensory evaluation of wines produced with different Moscato varieties
}

\author{
Â.R. Marcon ${ }^{1}$, L.V. Schwarz ${ }^{1}$, S.V. Dutra ${ }^{1}$, A.P.L. Delamare ${ }^{1}$, F. Gottardi ${ }^{2}$, G.P. Parpinello ${ }^{3}$, and S. Echeverrigaray ${ }^{1}$ \\ ${ }^{1}$ Instituto de Biotecnologia, Universidade de Caxias do Sul, 95070-560, Rio Grande do Sul, Brazil \\ ${ }^{2}$ Coop Italia. Via del Lavoro 6/8, 40033, Casalecchio di Reno, Bologna, Italy \\ ${ }^{3}$ Department of Agricultural and Food Sciences, University of Bologna, Piazza Goidanich 60, Cesena (FC), 47521, Italy
}

\begin{abstract}
Moscato grapes give very aromatic musts and wines, characterized by the presence of monoterpenoids. The Farroupilha region situated in the highlands of South Brazil, is responsible for 50\% of Brazilian Moscato wines production, and obtained its Geographical Indication (GI) in 2015. Brazilian Moscato wines are produced with several varieties, mainly Moscato Branco, Moscato Bianco R2 and Moscato Giallo. The objective of this study was to characterize the aromatic profile of wines produced with the three varieties. Microvinifications were conducted with grapes collected in three vineyards located in Farroupilha. Volatile compounds were evaluated using gas chromatography, and sensory characteristics were determined by a panel of enologists using a specific descriptive chard. Moscato Giallo wines exhibited the highest concentrations of ethyl acetate, 2-phenylethanol, isoamyl acetate, linalool, and $\alpha$-terpineol; Moscato R2 wines showed the highest concentrations of ethyl decanoate and nerol, while Moscato Branco wines, the most representative variety of Brazilian sparkling Moscato wines, exhibited the highest concentrations of ethanal and ethyl hexanoate, and intermediary concentrations of the other compounds. In sensory analysis, the three varieties exhibited pear, pitanga, rosemary, and citric fruits aromas, but in general, Moscato Giallo and Moscato R2 were more intense, while Moscato Branco showed the highest acidity.
\end{abstract}

\section{Introduction}

Moscato, Gewürztraminer, Sauvignon Blanc, and other varieties yield "aromatic wines", each one characterized by a strong and peculiar smell. Moscato wines exhibit pungent floral and fruity aromas, and sweet, spicy and fresh flavor [1]. These aromatic attributes can be readily perceived by sensory analysis and evaluated by chemical analysis of volatile compounds [2].

Moscato grapes are characterized by the presence of free and glycosylated monoterpenoids, and several aromatic precursors like fatty acids, cysteine conjugates, glycosides, and phenolic compounds [3,4]. Monoterpenes are isoprene compounds currently found in aromatic plants as hydrocarbons, aldehydes, alcohols, acids or esters. In Moscato grapes, the most important terpenes are linalool, geraniol, nerol, citronellol, and $\alpha$-terpineol, which are responsible for the characteristic floral notes of the wines [3-5]. However, the presence and concentration of these compounds in grapes and wines depend on several factors, like cultivar, climate, soil, agricultural practices, and winemaking process [6].

Brazilian white and sparkling Moscato wines are produced from Moscato Branco, Moscato Bianco R2, and Moscato Giallo, occasionally in blend with Moscato of Hamburg, Moscato Ottonel, Moscato of Alexandria, and some Malvasias varieties. These cultivars show particular aptitude for the production of typical aromatic and fresh wines, with low ethanol content and equilibrate acidity [7].

Moscato Branco is the most important Muscat variety cultivated in Southern Brazil with a production of approximately six million tons per year. For decades, this variety was considered the same as the traditional Italian Moscato Bianco, but recently, ampelographic, phenologic and molecular data showed that it is a different variety not related with anyone of those present in the Brazilian germplasm bank [8]. Although quite sensitive to ripe rot disease, Moscato Branco well adapt to South Brazilian soil and climate. It produces medium, compact and cylindrical bunches with spherical yellow berries. Their musts are sweet and exhibit a typical Muscat aroma [9].

With a production of approximately 620 thousand $\mathrm{kg}$ per year, Moscato Giallo is the second most important muscat cultivar. Their bunchs are larges and loose with straw yellow berries in Brazil. Grape shows high sugar content and low titratable acidity compared with other Moscato varieties [10].

Moscato Bianco is the typical variety used in the production of the Italian Moscato d'Asti, and its clone R2 is cultivated in South Brazil since the middle of the XX century, but its annual production is just 274 thousand $\mathrm{kg}$. It produces medium size pyramidal bunches with yellow berries, and under Brazilian conditions grapes show medium sugar content, high titratable acidity and the characteristic Moscato aroma.

Locally known as "Moscatel espumante", Brazilian Moscato sparkling wine is analogous to the Italian Moscato d'Asti wine. Brazilian Moscato wines production started in 1978 in the highlands of southern region, and grew specially at Farroupilha Region that represents approximately $50 \%$ of national production, obtaining its Geographical Indication (GI) in 2015. With approximately 
2.5 million bottles annually, Farroupilha produces for $50 \%$ of Brazilian Muscat sparkling wines [11]. Moreover, statistical data showed that the Brazilian production of Moscato sparkling wines increased $346 \%$ in a decade achieving 4.5 million liters in 2016 [11]. The success of Muscat sparkling wines in Brazil is associated with the tropical climate of the Country, that boosts the consumption of sweet, fresh and cold drinks [12,13].

In this context, the objective of the present work was to evaluate the chemical and sensory contribution of the most important varieties used in Brazilian Moscato wines production: Moscato Branco, Moscato Giallo, and Moscato Bianco R2.

\section{Materials and methods}

\subsection{Grape samples and microvinifications}

Physiological mature grapes samples $(20 \mathrm{~kg})$ from each variety were collected from three vineyards located in Farroupilha during the 2015 vintage.

Grapes were de-stemmed and pressed. The resulting juice was treated with metabisulfite $\left(50 \mathrm{mg} \mathrm{L}^{-1}\right)$, pectinolytic enzyme $\left(0.04 \mathrm{ml} \mathrm{L}^{-1}\right)$, and maintained at $2{ }^{\circ} \mathrm{C}$ for 5 days for clarification Then, musts were supplemented with $0.3 \mathrm{~g} \mathrm{~L}^{-1}$ of a commercial adjuvant (diammoniun phosphate, perlite and thiamine), and inoculated with Saccharomyces cerevisiae $\mathrm{X} 5\left(0.3 \mathrm{~g} \mathrm{~L}^{-1}\right)$. Fermentations (three replications of $4 \mathrm{~L}$ ) were conducted at $16^{\circ} \mathrm{C}$ for 15 days. After this period, wines were racked, stabilized at $-2{ }^{\circ} \mathrm{C}$ for 15 days, corrected to $50 \mathrm{mg} \mathrm{L}^{-1}$ free $\mathrm{SO}_{2}$, and bottled.

\subsection{Physicochemical analysis of musts and wines}

Ethanol concentration $(\% \mathrm{v} / \mathrm{v})$, density, $\mathrm{pH}$, total sugar $\left(\mathrm{g} \mathrm{L}^{-1}\right)$, total and free $\mathrm{SO}_{2}\left(\mathrm{mg} \mathrm{L}^{-1}\right)$, as well as titratable and volatile acidity $\left(\mathrm{g} \mathrm{L}^{-1}\right)$, were determined following the official methods described by Rizzon et al. [14]. Total phenolic compounds were determined by the FolinCiocalteau methods according with the OIV method [15] and expressed as $\mathrm{mg} \mathrm{L}^{-1}$ of gallic acid. Color intensity was determined by absorbance at $420 \mathrm{~nm}$.

\subsection{Analysis of volatile compounds}

The analysis of volatile compounds (esters, higher alcohols and terpenes) was performed using a gas chromatograph HP 6890 (Agilent Technologies, USA) with a capillary column CP Innowax $(30 \mathrm{~m} \times 250 \mu \mathrm{m} \times 0.25 \mu \mathrm{m}$, Agilent USA), and a flame ionization detector (FID). The compounds were identified by comparing the samples retention times with those of standards from SigmaAldrich.

Higher alcohols, acetaldehyde, ethyl acetate, methanol, as well as esters, acetates, and volatile acids were analyzed as described by Webber et al. [16], using 4-methyl-2pentanol and 3-octanol as internal standard, respectively.

The terpenes concentration (limonene, linalool, $\alpha$-terpineol, citronellol, nerol, geraniol and nerolidol) was analyzed using micro-solid phase extraction (SPME) with Polyacrilat fiber DVB/CAR/PDMS 50/30, and GC-FID analysis [17].
All the analysis were conducted in duplicates for each fermentation.

\subsection{Sensory analysis}

The sensory evaluation was conducted by a group of ten enologists on a specific evaluation sheet for Moscato white and sparkling wines, developed base on the OIV official chard [18], and the specific descriptors suggested by Zanus [13]. The wines were presented to the panelists at 8 to $10^{\circ} \mathrm{C}$ in standard wine-tasting glasses (ISO 3591, 1977). Wines were tasted in triplicate in a randomized order. Mineral water was provided for rinsing between each session.

The sensory descriptors were divided in visual (color intensity and tonality), olfactory (aroma intensity and quality, citric fruits (orange, pineapple), tropical fruits (papaya, guava, passion fruit, mango, and pitanga), tree fruits (peach, apple, pear), flowers (jasmine, roses, geranium), herbs (basil, rosemary, fennel, rue, mint), herbaceous aromas (fennel, vegetal), sweet aromas (honey, sweet potato, caramel), microbiological aromas (yeast, bread/toast, cheese/lactic), acetic aroma) and gustatory (flavor intensity, persistence, body/structure, sweetness, acidity, bitterness, undesirable flavors). All the attributes were evaluated using an intensity scale from 0 (no perception) to 5 (high intensity). Moreover, each judge was requested to give an overall quality score from 0 to 100 for each wine.

\subsection{Statistical analyses}

Mean differences were evaluated by one-way analyses of variance (ANOVA), and Tukey's test served as a post-hoc test, Spearman correlation, and the Principal Component Analysis (PCA) were also carried out. All of the analyses were carried out using the SPSS 22.0 software (IBM Analytics, Tulsa, USA).

\section{Results and discussion}

\subsection{Physicochemical parameters}

Table 1 show the physicochemical parameters of musts obtained from Moscato Bianco R2, Moscato Giallo and Moscato Branco produced at the "Serra Gaucha" region, Brazil. As can be observed, Moscato Giallo exhibited a significant highest sugar content and $\mathrm{pH}$, but an intermediary titratable acidity. Conversely, Moscato Bianco R2 showed the lowest concentration of soluble solids and highest titratable acidity characteristics of immature grapes. Moscato Giallo and Moscato Branco were collected in February, a period with a favorable maturation coefficient $(\mathrm{MQ}=2.0)$, while Moscato Bianco R2 ripened in January, a month with higher rainfull, that explains the anticipation of the harvest. The highest titratable acidity and lower alcoholic potential of Moscato Bianco R2 in Southern Brazil was reported in other vintages [19].

As expected, Moscato Bianco R2 wines exhibited the highest titratable acidity and lowest ethanol concentration. Moreover, this variety showed the lowest volatile acidity and the highest concentration of phenolic compounds 
Table 1. Physicochemical parameters of Moscato musts and wines.

\begin{tabular}{|c|c|c|c|}
\hline & Bianco R2 & Giallo & Branco \\
\hline \multicolumn{4}{|l|}{ MUSTS } \\
\hline Density & $1.0556 \pm 0^{\mathrm{b}}$ & $1.0697 \pm 0.01^{\mathrm{a}}$ & $1.0570 \pm 0.0^{\mathrm{b}}$ \\
\hline Brix $\left({ }^{\circ} \mathrm{Bx}\right)$ & $14.0 \pm 0.83^{\mathrm{b}}$ & $16.6 \pm 0.92^{\mathrm{a}}$ & $14.6 \pm 0.53^{\mathrm{b}}$ \\
\hline $\mathrm{pH}$ & $2.55 \pm 0.05^{\mathrm{c}}$ & $3.74 \pm 0.08^{\mathrm{a}}$ & $2.77 \pm 0.16^{\mathrm{b}}$ \\
\hline TA $\left(\mathrm{g} \mathrm{L}^{-1}\right)$ & $9.50 \pm 0.57^{\mathrm{a}}$ & $8.03 \pm 0.56^{\mathrm{b}}$ & $7.73 \pm 0.50^{\mathrm{b}}$ \\
\hline \multicolumn{4}{|l|}{ WINES } \\
\hline $\mathrm{VA}\left(\mathrm{g} \mathrm{L}^{-1}\right)$ & $0.26 \pm 0.03^{\mathrm{b}}$ & $0.43 \pm 0.11^{\mathrm{a}}$ & $0.38 \pm 0.11^{\mathrm{ab}}$ \\
\hline TA $\left(\mathrm{g} \mathrm{L}^{-1}\right)$ & $9.15 \pm 0.35^{\mathrm{a}}$ & $7.65 \pm 0.20^{\mathrm{b}}$ & $7.13 \pm 1.01^{\mathrm{b}}$ \\
\hline Density & $0.9940 \pm 0^{\mathrm{a}}$ & $0.9911 \pm 0^{\mathrm{b}}$ & $0.9924 \pm 0^{\mathrm{b}}$ \\
\hline $\mathrm{TS}\left(\mathrm{g} \mathrm{L}^{-1}\right)$ & $0.50 \pm 0.11^{\mathrm{a}}$ & $0.57 \pm 0.11^{\mathrm{a}}$ & $0.61 \pm 0.20^{\mathrm{a}}$ \\
\hline $\mathrm{pH}$ & $2.97 \pm 0.03^{\mathrm{b}}$ & $3.19 \pm 0.06^{\mathrm{a}}$ & $3.05 \pm 0.18^{\mathrm{ab}}$ \\
\hline Ethanol (\% vol) & $7.68 \pm 0.38^{\mathrm{b}}$ & $9.2 \pm 0.76^{\mathrm{a}}$ & $8.25 \pm 0.62^{b}$ \\
\hline Free $\mathrm{SO}_{2}\left(\mathrm{mg} \mathrm{L}^{-1}\right)$ & $9.17 \pm 4.14^{\mathrm{a}}$ & $9.81 \pm 2.08^{\mathrm{a}}$ & $9.18 \pm 2.48^{\mathrm{a}}$ \\
\hline Total $\mathrm{SO}_{2}\left(\mathrm{mg} \mathrm{L}^{-1}\right)$ & $46.8 \pm 6.64^{\mathrm{b}}$ & $61.0 \pm 19.5^{\mathrm{a}}$ & $61.6 \pm 29.7^{\mathrm{a}}$ \\
\hline TPC $\left(\mathrm{mg} \mathrm{L}^{-1}\right)$ & $147 \pm 13.9^{\mathrm{a}}$ & $120 \pm 4.67^{b}$ & $107 \pm 5.01^{\mathrm{b}}$ \\
\hline Color (AU) & $0.128 \pm 0.02^{\mathrm{a}}$ & $0.133 \pm 0.03^{\mathrm{a}}$ & $0.198 \pm 0.15^{\mathrm{a}}$ \\
\hline
\end{tabular}

* TA: titratable acidity, VA: volatile acidity; free $\mathrm{SO}_{2}$ : free sulfur dioxide; total $\mathrm{SO}_{2}$ : total sulfur dioxide; TPC: total phenolic compounds; TS: total sugar. Values followed by different letters within a line are significantly different at $p<0.05$ by the Tukey's test.

(Table 1). All the wines showed low color intensity, and a typical high tonality of Moscato and other white wines [20].

Although detrimental in red and white wines, high titratable acidity is considered as a desirable trait in sweet Moscato sparkling wines, contributing to the equilibrium and drinkability of the product [13].

\subsection{Volatile compounds}

Principal component analysis was used to analyze the data from the 28 identified compounds in the wines. The first two components explained $63.36 \%$ of the variance, and clearly separate the wines in three groups corresponding to the three Moscato varieties (Fig. 1).

PC1 that separated Moscato Giallo and Moscato Branco wines positively correlated $(>0.75)$ ethyl acetate, methanol, 1-propanol, isoamyl acetate, linalool, and $\alpha$-terpineol concentrations, and negatively correlated with the concentrations of hexyl acetate and 2-phenylethanol. On the other hand, PC2 separated Moscato Bianco R2 from the other two varieties and was positively correlated with the concentrations of ethyl decanoate and nerol, and negatively correlated with ethanal.

As can be observed in Table 2, twelve compounds $(42.8 \%)$ showed significant differences among wines. Moreover, some exceeded their odor threshold and can positive or negative affect the sensory characteristics of the wines $[3,21]$. In this view, it is interesting to point out the lower concentrations of 2-phenylethanol (rose aroma), and octanoic acid (undesirable butter note), in Moscato Giallo wines. Conversely, these wines showed the highest overall concentration of higher alcohols $\left(222.8 \mathrm{mg} \mathrm{L}^{-1}\right)$, and acetates $\left(29.3 \mathrm{mg} \mathrm{L}^{-1}\right)$. Although considered as undesirable compounds, low concentrations of higher alcohols $\left(<300 \mathrm{mg} \mathrm{L}^{-1}\right)$ can contribute to the increase of complexity of wines [22].

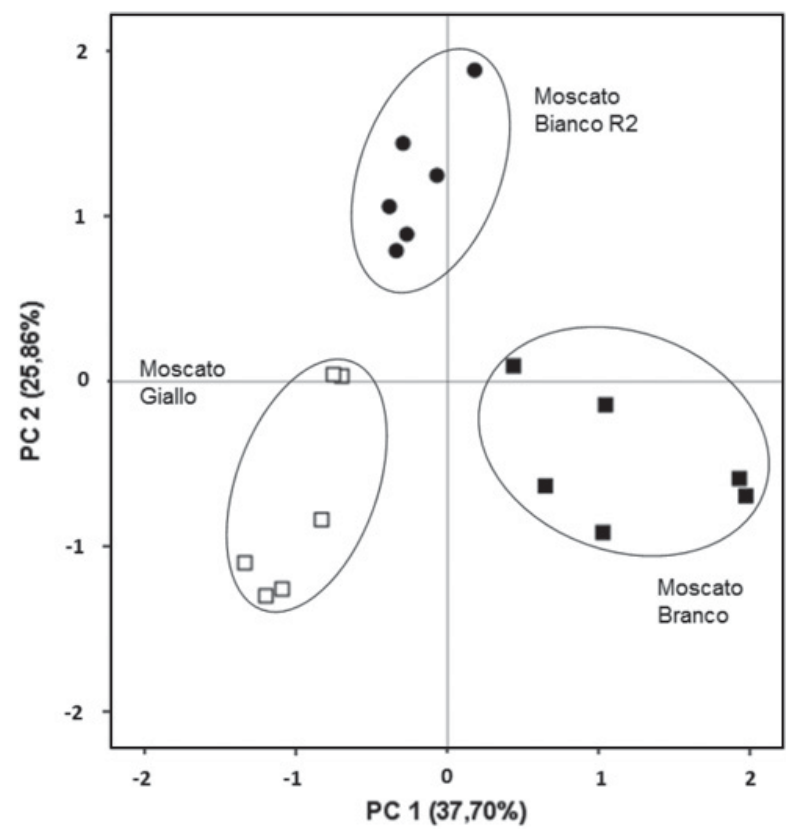

Figure 1. Principal Component Analysis (PCA) based on the concentration of volatile compounds of Moscato wines produced with three different varieties.

As expected, the three Moscato varieties yielded wines with high concentrations of monoterpenoids compared with non-aromatic wines [3]. The total concentrations of monoterpenoids was $2.28,3.35$, and $5.63 \mathrm{mg} / \mathrm{L}$ for Moscato Branco, Bianco R2, and Giallo, respectively, and all of them are within the range reported in aromatic wines [5,6]. However, the concentrations of citronellol and $\alpha$-terpineol were much higher compared to Moscato de Alexandria and Moscato Lefko [23], confirming the variation of free monoterpenes in different aromatic varieties, even those included in the Moscato group $[3,5,6]$. 
Table 2. Concentration $\left(\mathrm{mg} \mathrm{L}^{-1}\right)$ of volatile compounds in Moscato wines produced with three varieties.

\begin{tabular}{|c|c|c|c|c|}
\hline Volatile compounds & Bianco R2 & Giallo & Branco & Olfatory Threshold \\
\hline \multicolumn{5}{|l|}{ Aldehydes } \\
\hline ethanal & $13.1 \mathrm{~b}$ & $21.2 \mathrm{ab}$ & $29.7 \mathrm{~b}$ & 500 \\
\hline hexanal & $2.10 \mathrm{a}$ & $2.20 \mathrm{a}$ & $2.00 \mathrm{a}$ & 0.02 \\
\hline \multicolumn{5}{|l|}{ Higher alcohols } \\
\hline 1- propanol & $32.5 \mathrm{~b}$ & $82.0 \mathrm{a}$ & $35.4 \mathrm{~b}$ & 306 \\
\hline 2-methyl-1-propanol & $22.6 \mathrm{a}$ & $21.9 \mathrm{ab}$ & $18.7 \mathrm{~b}$ & 40 \\
\hline 2-methyl-1-butanol & $25.0 \mathrm{a}$ & $24.1 \mathrm{a}$ & $23.5 \mathrm{a}$ & 65 \\
\hline 3-methyl-1-butanol & $95.5 \mathrm{a}$ & $80.8 \mathrm{a}$ & $90.0 \mathrm{a}$ & 30 \\
\hline hexanol & $3.60 \mathrm{a}$ & $3.50 \mathrm{a}$ & $3.70 \mathrm{a}$ & 8.00 \\
\hline 2-phenylethanol & $18.9 \mathrm{a}$ & $10.5 \mathrm{~b}$ & $16.7 \mathrm{a}$ & 10.0 \\
\hline \multicolumn{5}{|l|}{ Acetates } \\
\hline ethyl acetate & $15.8 \mathrm{~b}$ & $23.5 \mathrm{a}$ & $18.4 \mathrm{ab}$ & 160 \\
\hline isomyl acetate & $2.20 \mathrm{a}$ & $2.90 \mathrm{a}$ & $1.00 \mathrm{~b}$ & 0.03 \\
\hline hexyl acetate & $2.60 \mathrm{a}$ & $2.60 \mathrm{a}$ & $2.80 \mathrm{a}$ & 0.67 \\
\hline phenylethyl acetate & $0.30 \mathrm{a}$ & $0.30 \mathrm{a}$ & $0.30 \mathrm{a}$ & 0.25 \\
\hline \multicolumn{5}{|l|}{ Volatile acids } \\
\hline octanoic acid & $8.30 \mathrm{a}$ & $6.60 \mathrm{a}$ & $8.80 \mathrm{a}$ & 0.50 \\
\hline decanoic acid & $7.30 \mathrm{a}$ & $6.90 \mathrm{a}$ & $7.10 \mathrm{a}$ & 10.0 \\
\hline \multicolumn{5}{|l|}{ Ethyl esters } \\
\hline ethyl butirate & $2.10 \mathrm{a}$ & $2.20 \mathrm{a}$ & $2.20 \mathrm{a}$ & 0.02 \\
\hline ethyl hexanoate & $1.70 \mathrm{~b}$ & $1.70 \mathrm{~b}$ & $2.30 \mathrm{a}$ & 0.01 \\
\hline ethyl octanoate & $4.90 \mathrm{a}$ & $5.10 \mathrm{a}$ & $4.80 \mathrm{a}$ & 0.005 \\
\hline ethyl decanoate & $0.60 \mathrm{a}$ & $0.40 \mathrm{ab}$ & $0.30 \mathrm{~b}$ & 0.20 \\
\hline \multicolumn{5}{|l|}{ Monoterpenoids } \\
\hline$(+)$ limonene & $0.02 \mathrm{a}$ & $0.04 \mathrm{a}$ & $0.03 \mathrm{a}$ & 0.02 \\
\hline$(-)$ rose oxide & $0.15 \mathrm{a}$ & $0.27 \mathrm{a}$ & $0.13 \mathrm{a}$ & 0.20 \\
\hline linalool & $0.28 \mathrm{~b}$ & $1.18 \mathrm{a}$ & $0.38 \mathrm{~b}$ & 0.05 \\
\hline linalyl acetate & $0.09 \mathrm{a}$ & $0.06 \mathrm{ab}$ & $0.04 \mathrm{~b}$ & $\mathrm{nf}$ \\
\hline$\alpha$-terpineol & $1.19 \mathrm{~b}$ & $2.43 \mathrm{a}$ & $0.76 \mathrm{c}$ & 0.40 \\
\hline citronellol & $0.24 \mathrm{a}$ & $0.20 \mathrm{a}$ & $0.22 \mathrm{a}$ & 0.02 \\
\hline nerol & $0.62 \mathrm{a}$ & $0.45 \mathrm{ab}$ & $0.34 \mathrm{~b}$ & 0.40 \\
\hline geraniol & $0.76 \mathrm{ab}$ & $1.00 \mathrm{a}$ & $0.38 \mathrm{~b}$ & 0.13 \\
\hline \multicolumn{5}{|l|}{ Others } \\
\hline methanol & $15.8 \mathrm{~b}$ & $29.6 \mathrm{a}$ & $18.4 \mathrm{~b}$ & $\mathrm{nf}$ \\
\hline diethyl succinate & $5.50 \mathrm{a}$ & $5.30 \mathrm{a}$ & $4.80 \mathrm{a}$ & 100 \\
\hline
\end{tabular}

* Means followed by different letters within a line are significantly different at $p<0.05$ by the Tukey's test. nf: not found.

\subsection{Sensory analysis}

The sensory analysis did not reveal significant differences between the three Moscato wines, and all of them received scores from 80 to 84 , denoting the absence of defects and a good overall liking.

Figure 2 shows the sensory values for olfactory and gustative attributes. Wines obtained from Moscato Bianco R2 and Moscato Giallo exhibited higher aromatic intensity, tropical fruits, tree fruits and sweetness than Moscato Branco, but Moscato Giallo showed higher microbial aroma than the other wines. Conversely, Moscato Branco wines obtained the lowest scores for most attributes, confirming its lowest aroma intensity.

While considering individual attributes, Moscato Bianco R2 and Moscato Giallo showed more intense peach, apple, pear, pitanga, and passion fruit aroma than Moscato Branco, and Moscato Bianco R2 obtained the highest scores for jasmine, roses, fennel, and honey. Moreover, judges identified sweet potato, yeast, and rue aromas in Moscato Giallo, while the highest pineapple and spices intensity were detected in Moscato Branco wines.

These results are similar to those found through the sensory analysis of 24 Australian Muscat sparkling wines in which tropical fruits, pear, apple, floral, honey, and candy aromas were present in almost all the samples, whereas some of them showed yeast, bread, and oak attributes, associated with wine evolution [12].

The highest aroma intensity and individual olfactory attributes of Moscato Giallo wines may be associated to their higher concentration of important aromatic compounds like hexanal, ethyl acetate, isoamyl acetate, phenylethyl acetate, ethyl hexanoate, and monoterpenoids (Table 2), that contribute with fruity and floral aromas $[3,21]$.

The wines elaborated with the three Moscato varieties showed similar flavor intensity, persistence and sharpness, but Moscato Branco wines were characterize by higher bitter taste than the others (Fig. 2B). Although characterized by medium acidity (Table 1 ), the wines were considered equilibrated and with low acid flavor. 

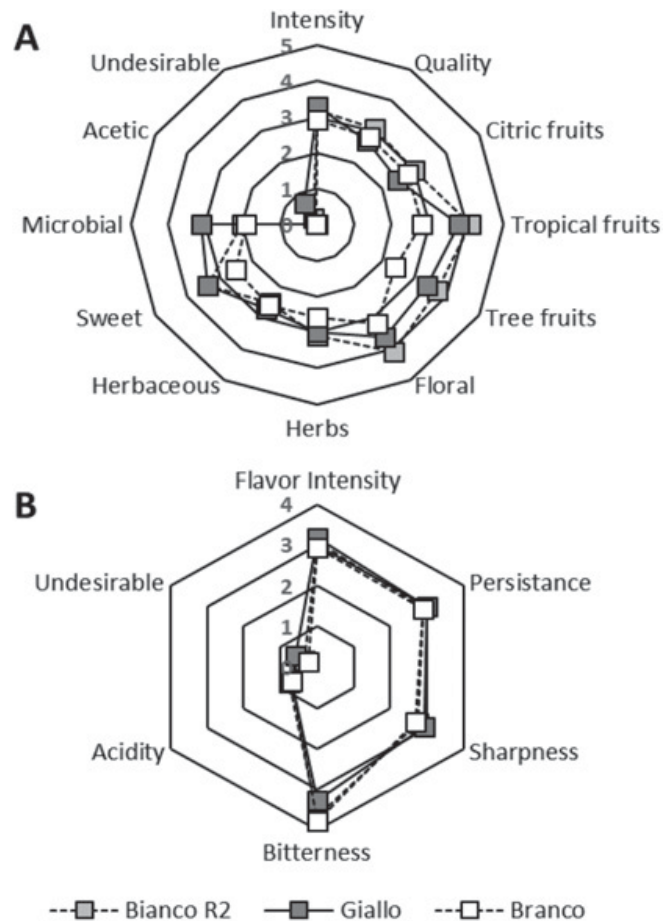

Figure 2. Sensory analysis of Moscato wines produced with Moscato Branco, Moscato Giallo, and Moscato Bianco R2. (A) Olfactory, and (B) Gustative attributes.

\section{Conclusion}

Significant differences were observed in the physicochemical characteristics and volatile composition of wines produced with three Moscato varieties currently used in white and sparkling Moscato wines in Southern Brazil. Moscato Giallo showed the highest sugar concentration and $\mathrm{pH}$, while Moscato Bianco R2, the most precocious variety, exhibited the lowest concentration of total soluble compounds and the highest titratable acidity.

The analysis of volatile compounds allowed to separate the wines obtained with the Moscato varieties. The main differences were based on the concentrations of higher alcohols (3-methyl-1-butanol, 2-phenylethanol), esters (ethyl acetate, isoamyl acetate, ethyl hexanoate), and monoterpenes (linalool, linalyl acetate, $\alpha$-terpineol, nerol). Moscato Giallo derived wines showed the highest concentration of overall volatile compounds.

Moscato Bianco R2 and Moscato Giallo wines showed higher aromatic intensity, tropical fruits, tree fruits, and sweet than Moscato Branco, while the highest pineapple and spices aroma were detected in Moscato Branco wines.

In general, the present work shows the contribution of different Moscato varieties on wines characteristics, which can help winemakers in the production of balanced and typical Moscato wines.

\section{References}

[1] C.C. Guerra, M.C. Zanus, Ann. I ${ }^{\text {st }}$ Intern. Workshop Research. Available on line: www . cnpuv. embrapa. br/publica/anais/wip2004/185.pdf (2004)
[2] I. Lesschaeve, Am. J. Enol. Vitic. 58, 252 (2007)

[3] P. Ribéreau-Gayon, Y. Glories, A. Maujean, D. Dubourdieu, Handbook of Enology 2. The Chemistry of wines, stabilization and treatments (John Wiley and Sons Ltd., Chichester, England, 2006)

[4] C. González-Barreiro, R. Rial-Otero, B. CanchoGrande, J. Simal-Gándara, J. Crit. Rev. Food Scien. Nutr. 55, 202 (2015)

[5] J.J. Mateo, M. Jiménez, J. Chromat. A. 881, 557 (2000)

[6] J. Marais, S. Afri. J. Enol. Vitic. 4, 49 (1983)

[7] L.A. Rizzon, A.M. Gasparin (Available online: http://sistemasdeproducao cnptia. embrapa . br/FontesHTML/Vinho/SistemaProducaoVinho MoscatelEspumante/introducao.htm (2018)

[8] P. Ritschel, F.G.G. Gomes, I. Ceriotti, P. Longhi, J.D.G. Maia, M.C. Zanus, J. Tonietto, M.E. Ferreira, Proc. Int. Crop Sci. Congress, Bento Gonçalves, Brazil, 3128 (2012)

[9] U.A. Camargo, Frutas do Brasil 34, 34 (2003)

[10] Cadastro vitícola, Available online: http://www. cnpuv . embrapa.br/cadastro-viticola/rs2013-2015/home.html (2015)

[11] Ibravin 2017

[12] J.A. Culbert, R. Ristic, L.A. Ovington, A.J. Saliba, K.L. Wilkinso, Austr. J. Grape Wine R. 24, 96 (2018)

[13] M.C. Zanus, Espumante Moscatel - o sabor certo para sua sobremesa, Available online: http://www . cnpuv .embrapa.br/publica/artigos/moscatel. html (2014)

[14] L.A. Rizzon, Metodologia para análise de vinho (Embrapa Informação Tecnológica, Brasília, 2010)

[15] OIV-MA-AS2-10, Avaliable online: http://www. oiv.int/public/medias/2326/oiv-ma-as2-10. pdfOIV (2009)

[16] V. Webber, V.S. Dutra, F.R. Spinelli, A.R. Marcon, G.J. Carnieli, R. Vanderlinde, Food Chem. 159, 391 (2014)

[17] R.D. Soares, J.E. Welke, K.P. Nicolli, M. Zanus, E.B. Camarão, V. Manfroi, C.A. Zini, Food Chem. 183, 291 (2015)

[18] OIV Available online: http://www.oiv.int/ public/medias/4661/oiv-concours-332a2009-en.pdf (2009)

[19] R. Del Sávio, Monography. IFRS, Bento Gonçalves, Brazil (2011)

[20] G. Chavarria, H.P. Santos, M.C. Zanus, C. Zorzan, G.A.B. Marodin, Pesq. Agropec. Bras. 43, 911 (2008)

[21] V. Ferreira, R. López, J.F. Cacho, J. Sci. Food Agric. 80, 1659 (2000)

[22] C. Flanzy, Enología: fundamentos científicos y tecnológicos (Ediciones Mundi-Prensa, Madrid, 2000)

[23] P. Lanardis, M.J. Salaha, I. Tzourou, E. Tsoutsouras, S. Karagiannis, J. Int. Sci. Vigne Vin. 36, 39 (2003) 